Zheliazkov Y.

\title{
CIRCUIT DESIGN OF BUCK-VOLTAGE CONVERTER WITH DIGITAL CONTROL SYSTEM
}

Об’єктом дослідження є процеси в електричній схемі та величезні цифрові системи управління в перетворювачі. Одним з найбільш проблемних місць є передача та зміна енергї в перетворювачах струму та напруги для досягнення відповідного значення числового діапазону з мінімальним відсотком похибки.

В даній роботі досліджуться понижуючий перетворювач напруги з цифровою системою керування, зокрема розглянуто порядок проектування електричної схеми. Описано електричну схему з системою керування, яка за допомогою иифрової системи забезпечує дані з більш точною напругою на виході конвертера, а саме: завдання відповідного числового діапазону вихідної напруги та вплив системи на роботу схеми.

В ході дослідження використовувався набір апаратних та програмних засобів, в тому числі периферійні пристрої, які дозволяють досить просто та швидко налаштувати мікроконтролер на потрібний режим роботи та програмно реалізувати систему керування понижуючого перетворювача.

Проаналізовано послідовність вирішення та вибору певних частин електричної схеми, при побудові якої було використано:

- мікроконтролер для прийому, обробки та видачі інформащії в електричному колі;

- керування драйвером та роботи аналого-цифрового перетворення в схемі;

- драйвер для керування ключами - транзисторами;

- компоненти схеми понижуючого перетворювача.

Зроблено опис та вибір частин схеми за такими параметрами та характеристиками:

- для понижуючого перетворювача - такі елементи, як ключ, діод та конденсатор;

- мікроконтролера - відповідний діапазон частоти та напруги;

- драйвера - керування силовими ключами схеми з відповідними робочими параметрами.

Отримано систему, яка в перспективі стане підгрунтям для пониження значення напруги до відповідного рівня. Це пов'язано з тим, що запропонований метод має ряд особливостей, зокрема цифрову систему регулювання з дискретним кроком та аналого-цифровим перетворювачем в якості зворотнього зв'язку. Завдяки цьому забезпечується можливість отримання більш коректного значення показників. У порівнянні з аналогічними понижуючими перетворювачами, даний конвертер має показник напруги з можливою незначною похибкою.

Ключові слова: понижуючий перетворювач, керований сигнал, гальванічна розв'язка силової частини, цифрове керування.

\section{Introduction}

There is often happens situation, in which voltage value of the internal source can be low or big for reliable working process. For example, in order wireless charging systems could transfer voltage in range of 5-7 volts for certain devices or 70-80 volts for certain autos. Actually, voltage value could be not enough or more level, than it is necessary. In order to solve this problem it is possible to use electrical filters and additional resistors with other components. The problems of it are great volume and big weight, exploitation conditions for connection system comes wrong. Therefore, it is efficiently to use buck-converter in order to receive certain value. Analogic researches were made in [1] for boost-voltage converter with digital system control and in [2] for buck-boost converter with voltage feedback control. Therefore, the objects of research are processes in electrical scheme and enormous digital control systems in converter. The aim of the article is projecting, researching and practical realization of semiconducting voltage buck converter with digital system control.

\section{Methods of research}

2.1. Calculation of parameters in buck converter scheme. There is in Fig. 1 an electrical principle scheme of the buck voltage converter. Power circuit of converter has transistor $V T_{1}$. If the key switched on, output current, which flows through the inductance coil $(L)$, rises. Inductance coil is coupling magnetic field energy. If the key switched off, coupled electrical energy in the inductance coil will be send to the capacitor $(C)$ and load $\left(R_{L}\right)$. Bypass diode $\left(V D_{1}\right)$ lets the pass for the current to flow.

In order to realize the scheme it is important to calculate nominals of the elements in the buck converter [3, 4]. 
Calculation would be finished with a certain parameters: maximal output current $I_{\text {out } \text { max }}=0.46 \mathrm{~A}$, frequency switching $f_{\text {sw }}=10 \mathrm{kHz}$, inductive current ripple factor $L I R=0.3$, range of input voltage $U_{i n}=7-24 \mathrm{~V}$ and output voltage $U_{\text {out }}=5 \mathrm{~V}$.

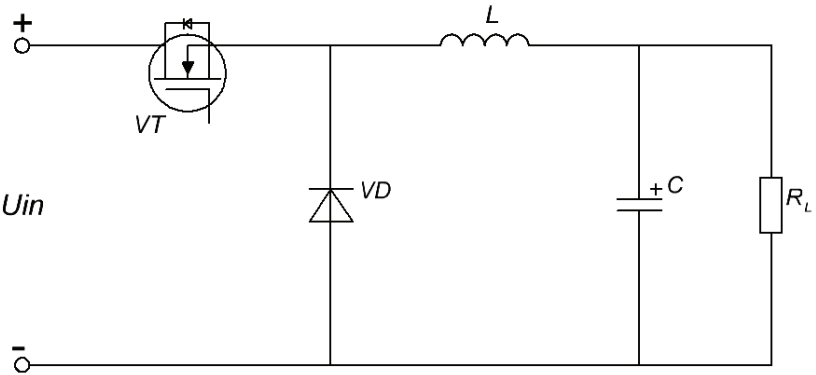

Fig. 1. Scheme of the buck converter

Inductance calculation is an important moment during converter projecting, insofar as there is dependence on values of maximal input $U_{\text {in.max }}$ and output $U_{\text {out }}$ voltage:

$$
\begin{aligned}
& L=\left(U_{\text {in } \max }-U_{\text {out }}\right) \frac{U_{\text {out }}}{U_{\text {in.max }}} \frac{1}{f_{\text {sw }}} \frac{1}{L I R \cdot I_{\text {out } \max }}, \\
& L=(24-5) \mathrm{V} \frac{5 \mathrm{~V}}{24 \mathrm{~V}} \frac{1}{10^{4} \mathrm{~Hz}} \frac{1}{0.3 \cdot 0.46},
\end{aligned}
$$

where $f_{s w}$ - frequency switching transistor; LIR - inductive current ripple factor; $I_{\text {out max }}-$ maximal value of output current.

Peak current of the inductance coil $I_{\text {peak }}$ solves as:

$$
\begin{aligned}
& I_{\text {peak }}=I_{\text {out } \max }+\frac{\Delta I_{\text {ind }}}{2}, \\
& I_{\text {peak }}=0.46 \mathrm{~A}+\frac{0.3 \cdot 0.46 \mathrm{~A}}{2}=0.53 \mathrm{~A},
\end{aligned}
$$

where $\Delta I_{\text {ind }}=L I R \cdot I_{\text {out max }}$ - variable inductance value.

Output capacitor with a maximum available amplitude swing of ripples of the output voltage $\Delta U$ (accept $\Delta U=100 \mathrm{mV})$ :

$$
\begin{aligned}
C_{\text {out }} & =\frac{L}{\left(\Delta U+U_{\text {out }}\right)^{2}-U_{\text {out }}^{2}}\left(I_{\text {out } \text { max }}+\frac{\Delta I_{\text {ind }}}{2}\right), \\
C_{\text {out }} & =\frac{2.87 \mathrm{mH}}{(100 \mathrm{mV}+5)^{2}-5^{2}}\left(0.46+\frac{0.138}{2}\right)^{2}=0.8 \mathrm{mF} .
\end{aligned}
$$

Capacitance of the input capacitor, including of the load current $I_{L}$ and swing of ripples of the output voltage $U_{\text {out.ripple }}$ :

$$
\begin{aligned}
& C_{\text {out }}=\frac{I_{L}}{2 \pi f_{\text {swe }} U_{\text {out.ripple }}}, \\
& C_{\text {in }}=\frac{0.46 \mathrm{~A}}{2 \cdot 3.14 \cdot 10^{4} \mathrm{~Hz} \cdot 40 \mathrm{mV}}=183 \mathrm{uF} .
\end{aligned}
$$

Duty cycle of the open state power key relative period of the pulse width modulation:

$$
D=\frac{U_{\text {out }}}{U_{\text {in }}}=\frac{5 \mathrm{~V}}{12 \mathrm{~V}} \approx 0.42 \approx 42 \% .
$$

2.2. Choice of microcontroller in electrical scheme. It was selected integral scheme PIC16F877A as microcontroller in Fig. 2 [5, 6]. This scheme is very convenient for a work, coding of this controller is not so difficult. One of the main advantages is that it can be write-erase as many times as possible because it uses FLASH memory technology. It has a total number of 40 pins and there are 33 pins for input and output.

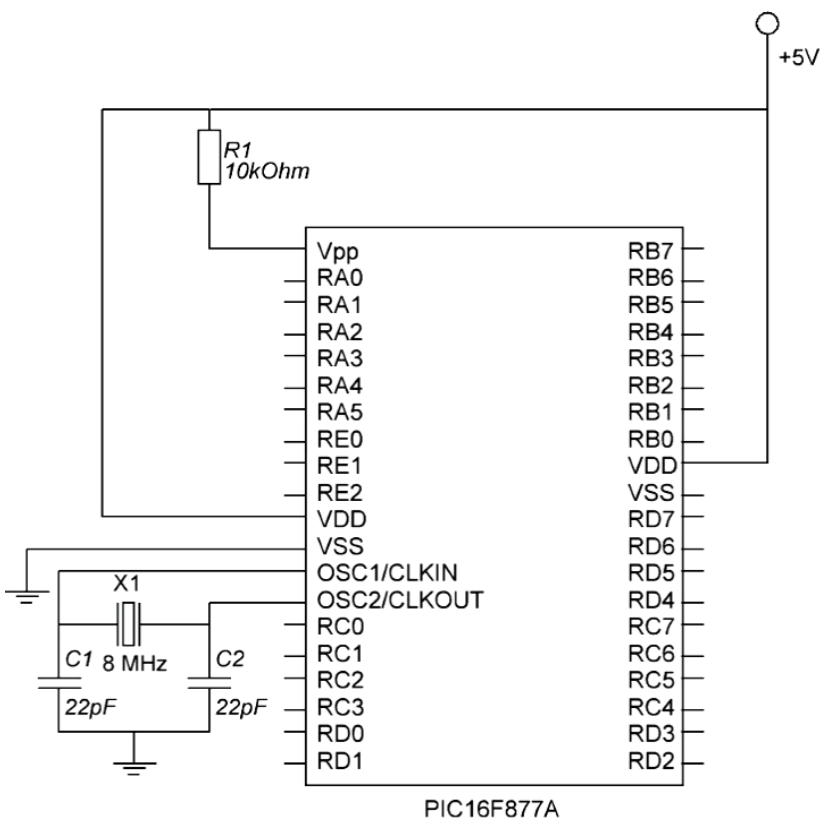

Fig. 2. Scheme of microcontraller PIC16F877A with a peripheral part

PIC16F877A finds its applications in a huge number of devices. It is used in security, remote sensors and safety devices, home automation and many industrial instruments. An enormous EEPROM is also featured in it which makes it possible to store some of the information permanently like transmitter codes and receiver frequencies and some other related data. The cost of this controller is not expensive and its handling is also easy. It is flexible and can be used in areas where microcontrollers have never been used before as in microprocessor applications and timer functions etc. It works in a range until $20 \mathrm{MHz}$ and in a range of voltage $4.2-5.5 \mathrm{~V}$.

2.3. Choice of the driver in electrical scheme. It was selected IR2184S as driver in Fig. 3, as it is driver MOSFET of the high voltage in the integrated scheme [7-9]. It can control by the keys in the half-bridge and bridge schemes of the low resistance both with high and low level. Schemes of the drivers are using MOSFET with high and low level.

Gate drive supply range from 10 to $20 \mathrm{~V}$, output source capability is equal to $1.4 \mathrm{~A}$ and sink current capability is equal to $1.8 \mathrm{~A}$, time to switch on $t_{o n}=120 \mathrm{nS}$ and to switch off $t_{\text {off }}=94 \mathrm{nS}$, tolerant to negative transient voltage, operates up to $600 \mathrm{~V}$. 


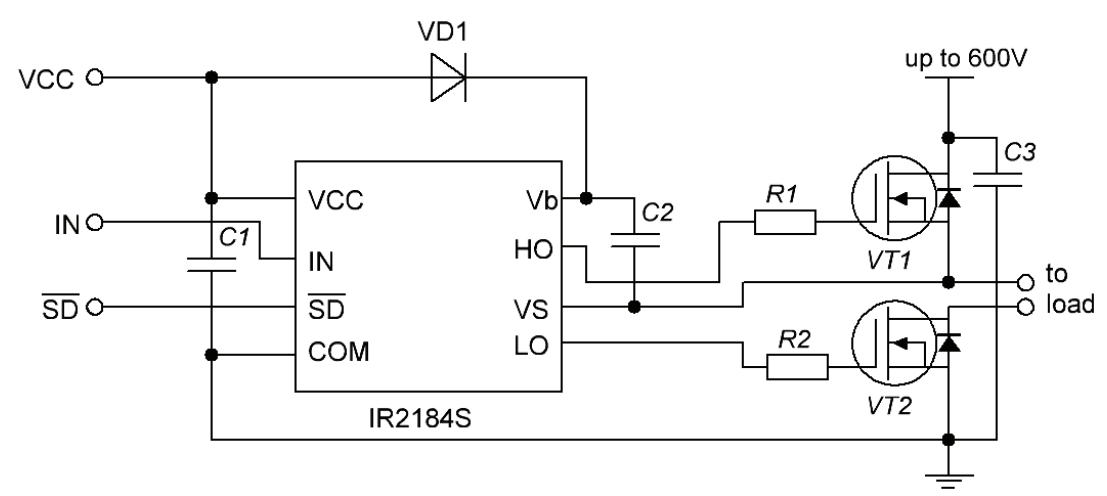

Fig. 3. Integrated scheme of the driver IR21845

\section{Research results and discussion}

3.1. The result of engineering of the electrical scheme. After the selection of the certain elements and engineering of controlling system there was projected in Fig. 4 electrical scheme with components and microcontroller, which takes part in a work of buck converter and control of digital signals. There is PIC16F877A.

As a basis, there was taken [10]. With this set of bundled hardware and software, it is quite quick and easy to set up the microcontroller to the certain operating mode and to implement the buck converter control programmatically.

In order to provide galvanic isolation of the power circuit and controlling system, transmission impulse of controlling was made with the using of the half-bridge driver IR2184S.

3.2. The results of the experiment. Electric principle scheme in Fig. 4 was projected and modulated in the programmed application Proteus, which model represented.

In Fig. 5 there is a general form of buck converter realization in program.

In Fig. 6 there is represented realization of the model of buck converter with a digital controlling system in programmed application Proteus that relates to the electrical principle scheme in Fig. 4.

Fig. 7 is represented researching of the graphics of projected buck converter with a defined voltage of input voltage $12 \mathrm{~V}$ and output voltage $-5 \mathrm{~V}$. In order to support constant output voltage, regulator changes porosity of the controlling signal. An enormous, in Fig. 7, a demonstrated signal of the pulse width modulation (PWM) that flows to MOSFET transistor IRF540 and output voltage in Fig. 7, $b$.

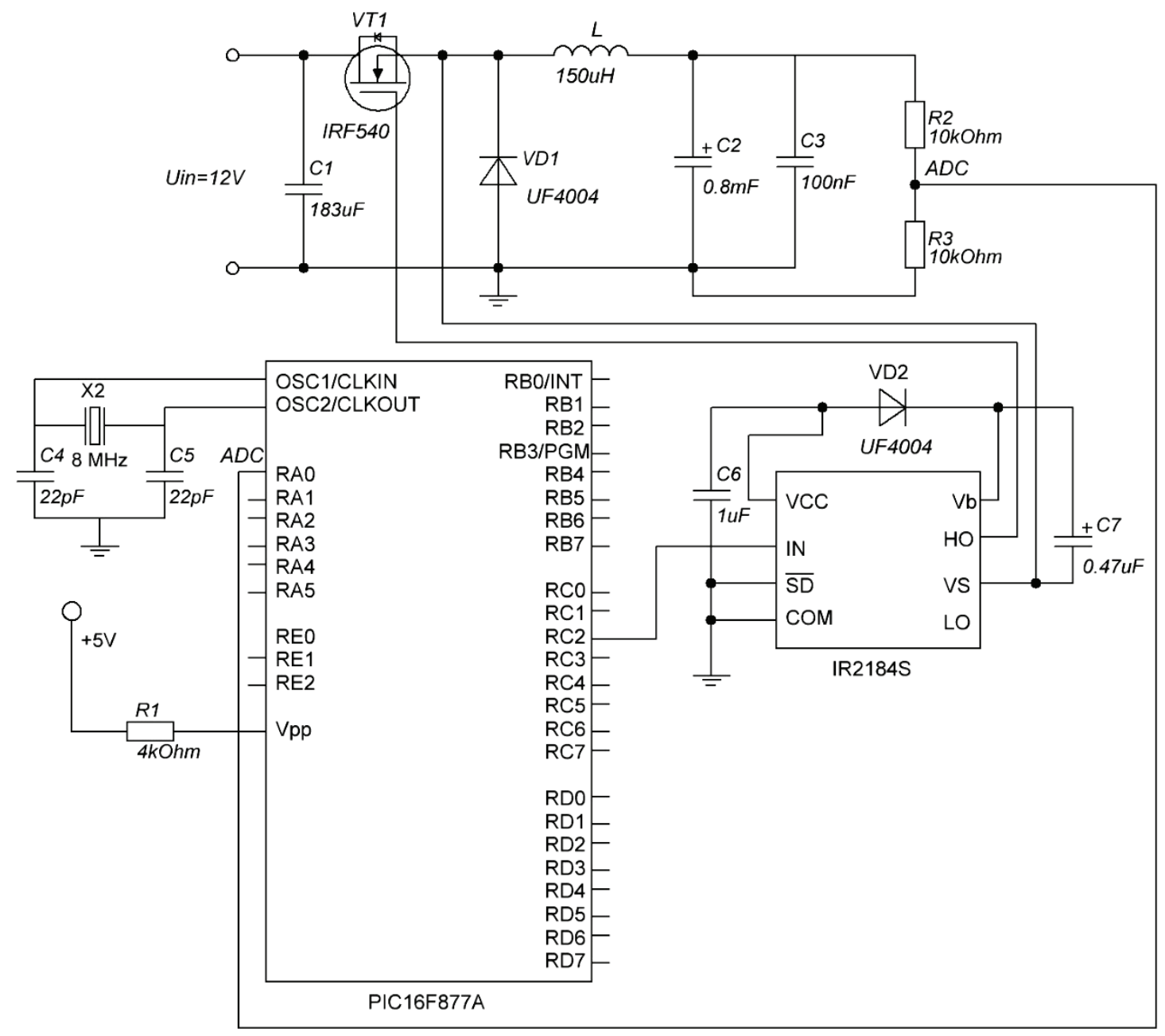

Fig. 4. Electric principle scheme with converter of the controlling and regulating system 


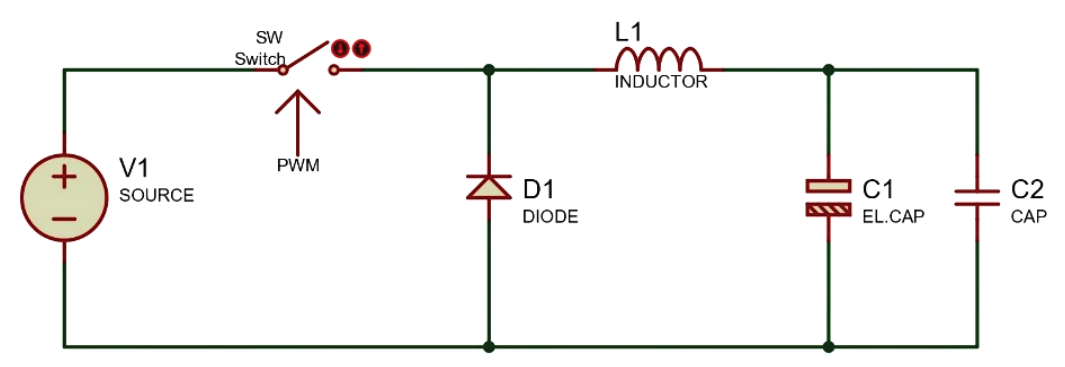

Fig. 5. General form of buck converter realization in program Proteus

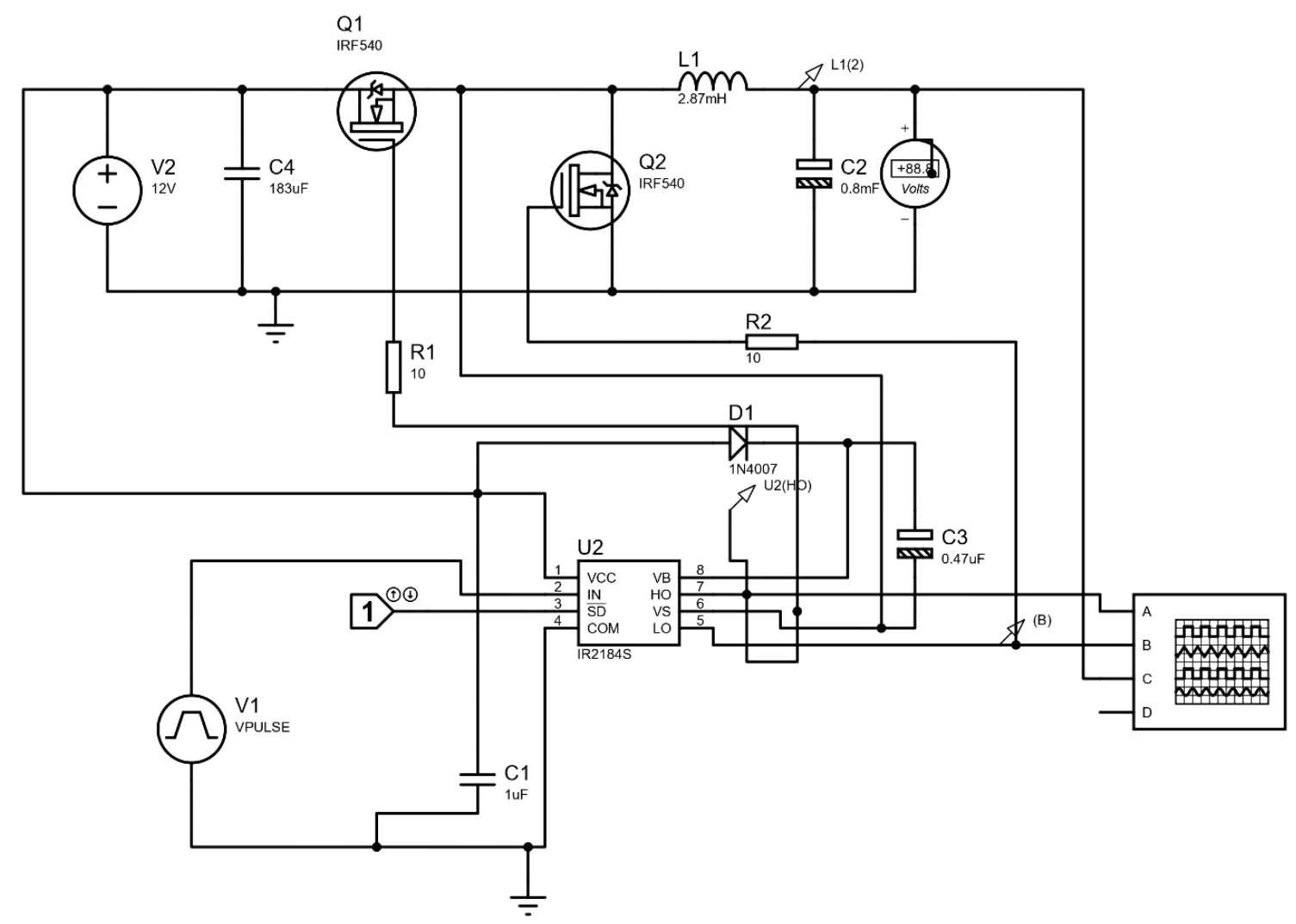

Fig. 6. Model of buck converter with a digital controlling system in programmed application Proteus
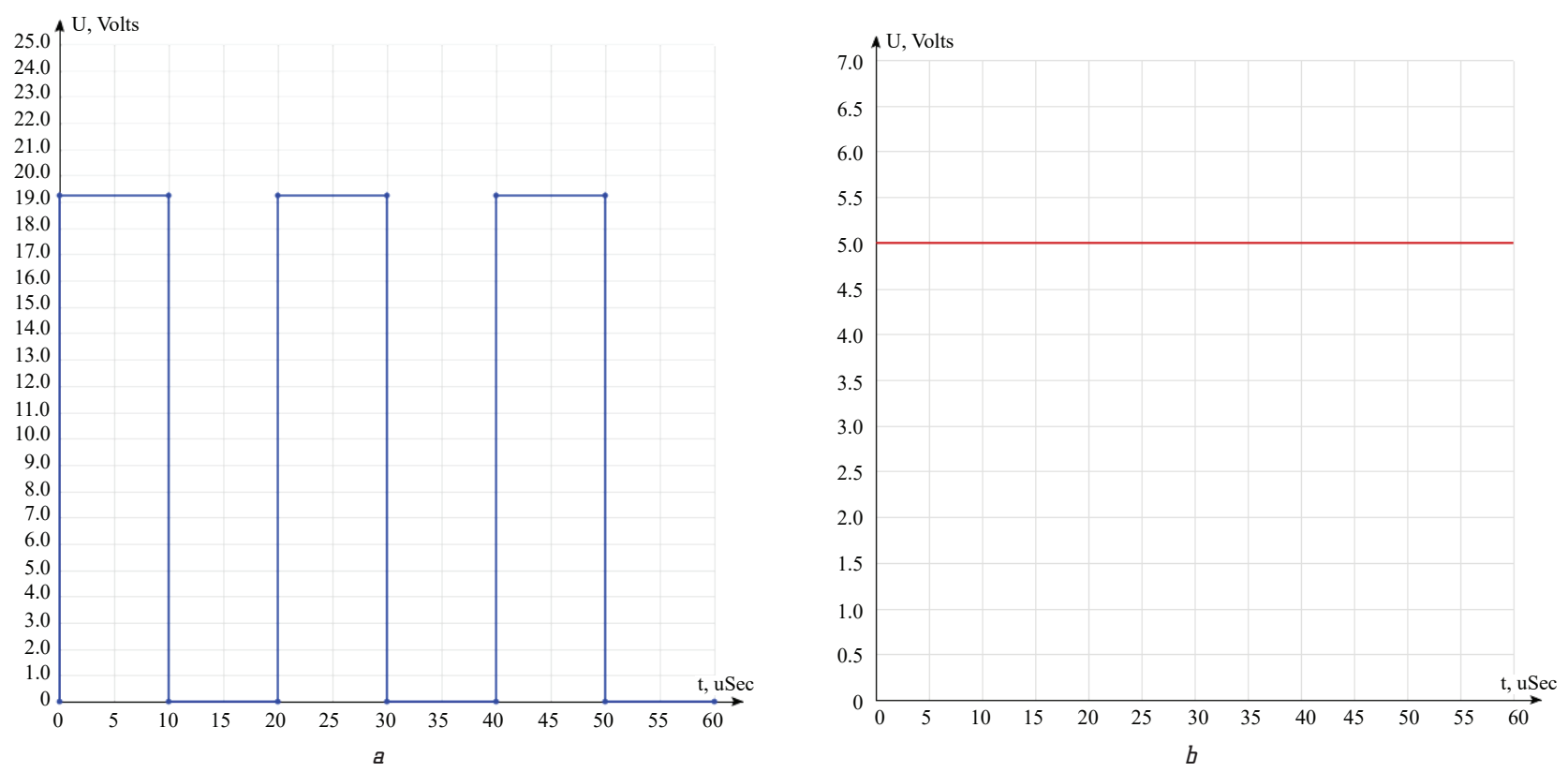

Fig. 7. Controlling signals of converter: $a$ - pulse width modulation; $b$ - output voltage 
All over the elements are playing a main role in the converter. To be sure, there was considered capability of the scheme to work without capacitor $C_{\text {out }}$. It is obviously, that output capacitor rectify voltage and the voltage is rippling in output of converter.

\section{Conclusions}

There was developed principle of the technical realization of the semiconducting buck voltage converter. It can be used in a lot of devices. There was analyzed capability to create power supply equipment based on PWM for the input voltage of the discrete current. There also was researched that for practical realization of the buck voltage converter, which was based on inductive-capacitive converter, it is conveniently using of the digital system controlling. According to the certain graphics in Fig. 7, $a$ and Fig. 7, b, scheme was successfully tested.

\section{References}

1. Dymko, S. S., Teriaiev, V. I. (2020). Pidvyshchuiuchyi peretvoriuvach napruhy z tsyfrovoiu systemoiu keruvannia. Suchasni problemy elektroenerhotekhniky ta avtomatyky, 427-431.

2. Zhou, X., He, Q. (2015). Modeling and Simulation of BuckBoost Converter with Voltage Feedback Control. MATEC Web of Conferences, 31, 10006. doi: http://doi.org/10.1051/matecconf/ 20153110006

3. Rashid, H. (Ed.) (2001). Power Electronics Handbook. Academic Press series in engineering, 254.

4. Schell, D., Kastorena, Zh. (2007). Razrabotka ponizhayushchego preobrazovatelya bez sekretov. Komponenty $i$ tekhnologii, 4, 106-109.

5. PIC16F877A Microcontroller Introduction and Features. Available at: https://microcontrollerslab.com/pic16f877a-introductionfeatures/

6. PWM using Pic Microcontroller with Examples. Available at: https://microcontrollerslab.com/pwm-using-pic16f877a-microcontroller/

7. How to use MOSFET/IGBT DRIVER IR2184S. Available at: https://www.hobbytronics.co.uk/ir2184-mosfet-driver

8. IR2184 High and Low Side MOSFET Driver. Available at: https:// www.hobbytronics.co.uk/ir2184-mosfet-driver

9. Spravochnik po elektronnym komponentam IR2184, IR21844 «Draiver klyuchei nizhnego i verhnego uroonei». Available at: http://www. gaw.ru/html.cgi/txt/ic/IR/control/drivers2/2/IR2184 844.htm

10. Buck converter using pic microcontroller and IR2110. Available at: https://microcontrollerslab.com/buck-converter-using-picmicrocontroller-ir2110/

Zheliazkov Yehor, Department of Electronic Devices and Systems National Technical University of Ukraine «Igor Sikorsky Kyiv Polytechnic Institute»,Ukraine, e-mail:yehor.zheliazkov@i.ua, ORCID: http:// orcid.org/0000-0002-3651-7840 